\begin{tabular}{cc|c}
\hline Tar. Bil. Der. & Journal of Agricultural Sciences \\
& $\begin{array}{c}\text { Dergi web sayfası: } \\
\text { www.agri.ankara.edu.tr/dergi }\end{array}$ & Journal homepage: \\
& www.agri.ankara.edu.tr/journal
\end{tabular}

\title{
Osmaniye'de Yetiştirilen Yerfistıklarında Hasat, Hasat Sonrası, Kurutma ve Depo Öncesi Dönemlerinde Aflatoksin Oluşumu
}

\author{
Işılay LAVKOR ${ }^{\mathrm{a}}$, Mehmet Bíçící \\ a Biyolojik Mücadele Araştırma İstasyonu, Adana, TÜRKIYYE \\ ${ }^{\boldsymbol{b}}$ Çukurova Üniversitesi, Ziraat Fakültesi, Bitki Koruma Bölümü, Adana, TÜRKIYE
}

\section{ESER BİGISİ}

Araştırma Makalesi

DOI: 10.1501/Tarimbil_0000001342

Sorumlu Yazar: Işılay LAVKOR, E-posta: lavkor@gmail.com, Tel: +90 (322) 3441702

Geliş Tarihi: 16 Nisan 2014, Düzeltmelerin Gelişi: 22 Ağustos 2014, Kabul:16 Eylül 2014

\begin{abstract}
ÖZET
Aflatoksin bulaşması yerfıstığı ve ürünlerinde rastlanan önemli sorunlarından biridir. Bu çalışmada Osmaniye'de yetiştirilen yerfıstığı ürününde farklı dönemlerdeki toplam aflatoksin seviyelerinin ve bu toksin oluşumları için kritik dönemlerin belirlenmesi amaçlanmıştır. Çalışma, 2010-2011 yılları arasında Osmaniye'de deneme ve araştırma alanlarında yürütülmüştür. Yerfıstığı tanelerinin toksin analizi için hasat, hasat sonrası, kurutma ve depo öncesi olmak üzere toplam 4 dönemde örnekler alınmıştır. Toplam aflatoksin oluşumları CD-ELISA (Competitive Direct-Enzyme Linked Immuno Sorbent Assays) yöntemi ile belirlenmiştir. Toksin analizleri sonucunda, deneme alanında bez üzerinde kurutulan 96 yerfıstığı örneğinde aflatoksin kirliliği saptanmazken, araştırma alanlarında toprak zemin üzerinde kurutulan 42 yerfıstığ 1 tane örneğinin 41 'inde $0.1-9.0 \mu \mathrm{g} \mathrm{kg}^{-1}$ arasında toksin bulaşıklığ 1 belirlenmiştir. Aflatoksin kirliliği içerdiği belirlenen 18 adet yerfıstığı tane örneğine IAC-HPLC (Immunoaffinity Chromatography-Reversed-Phase HighPerformance Liquid Chromatography) uygulanmıştır. Her iki yöntemle belirlenmiş aflatoksin kirlilikleri birbirine çok yakın değerler olmuştur. Aflatoksin düzeyleri; kurutma ve depo öncesi dönemde, hasat ve hasat sonrasına göre daha yüksek bulunmuştur. Sonuç olarak, kurutma ve depo öncesi evrelerinin aflatoksin oluşumu için kritik dönemler olduğu sonucuna ulaşılmıştır.
\end{abstract}

Anahtar Kelimeler: Aflatoksin; CD-ELISA; IAC-HPLC; Yerfistığ 1

\section{Aflatoxin Occurrence in Peanuts Grown in Osmaniye at Harvest, Post- Harvest, Drying and Pre-Storage Periods}

\section{ARTICLE INFO}

Research Article

Corresponding Author: Iș1lay LAVKOR, E-posta: lavkor@gmail.com, Tel: +90 (322) 3441702

Received: 16 April 2014, Received in Revised Form: 22 August 2014, Accepted: 16 September 2014

\section{ABSTRACT}

Aflatoxin contamination is one of the important problems on peanuts and their products. The aim of the study was to detect aflatoxin occurrence and critical periods of toxin production on peanuts collected in different periods. The study 
was carried out in the years of 2010 and 2011 at experimental and different research areas of Osmaniye. Peanut kernels toxin analysis was performed at four distinct periods during the harvesting process: harvest, post-harvest, drying and pre-storage. Total aflatoxin occurrence on peanut kernels was analyzed by CD-ELISA (Competitive Direct-Enzyme Linked Immuno Sorbent Assays). Analysis results showed that aflatoxin contamination was not found on 96 samples sundried on drying sheet at experimental area whereas 41 of 42 samples sundried on field soil at the research areas were contaminated. Toxin levels in 42 contaminated samples were from 0.1 to $9.0 \mu \mathrm{g} \mathrm{kg}^{-1}$. Also, IAC-HPLC (Immunoaffinity Chromatography-Reversed-Phase High-Performance Liquid Chromatography) analysis was used for the 18 samples contiminated aflatoxin. The results from both the CD-ELISA and IAC-HPLC analysis were similar. Aflatoxin levels during drying and pre-storage were significantly higher than those during harvest and post-harvest. In conclusion, the drying and pre-storage terms are the most critical periods for aflatoxin contamination.

Keywords: Aflatoxin; CD-ELISA; IAC-HPLC; Peanut

(C) Ankara Üniversitesi Ziraat Fakültesi

\section{Giriş}

Yerfıstığ1 (Arachis hypogaea L.), Fabaceae familyasına ait tek yıllık bir bitki olup, tohumunda yüksek oranda yağ içermektedir. Yerfıstığ 1 insan gıdası, hayvan yemi ve endüstrinin çeşitli alanlarında kullanılmaktadır (Arıoğlu 2007). Ülkemizde yerfıstığı üretimi en fazla Adana (68375 ton) ilinde yapılmakta, bunu Osmaniye (42113 ton), Kahramanmaraş (16325 ton), Aydın (5236 ton), Antalya (3346 ton), Mersin (1673 ton), Hatay (1150 ton), Gaziantep (520 ton) ve Muğla (300 ton) illeri izlemektedir (TUIK 2013).

Yerfıstığında diğer bitkilerde olduğu gibi, biyotik ve abiyotik hastalıklar üretimi ve verimi azaltmaktadır. Özellikle, çıkış öncesi tohum çürüklükleri (Rhizopus spp., Aspergillus niger, A. flavus, Penicillium spp., Fusarium spp., Rhizoctonia solani), kök boğazı çürüklüğü (Aspergillus niger), gövde çürüklüğü (Sclerotium rolfsii), erken ve geç yaprak lekesi (Cercospora arachidicola, Cercosporodium personatum) ve meyve çürüklüğü (Pythium myriothylum) gibi hastalıklar son derece önemlidir.

Fungal hastalık etmenleri, tarımsal ürünlerde hastalık oluşturarak zarar vermelerinin yanı sıra, bazıları da ikincil metobolizma faaliyetleri sonucu ürettikleri mikotoksinlerle insan, hayvan ve hatta diğer bitkilere toksijenik yan etkiler vermekte ve ürünlerde ekonomik kayıplara neden olmaktadır (GIBSA 2006; Amaike \& Keller 2011; Negedu et al
2011). Mikotoksin oluşumunun en fazla görüldüğü tarım ürünleri; tahıllar, yağlı tohumlular, kırmızı pul biber, kahve, kakao ve özellikle üzüm, incir gibi kurutulmuş meyvelerdir. Yerfıstığı ve ürünleri bütün dünyada mikotoksin; özellikle de aflatoksin kontiminasyonu açısından en riskli gıda olarak bilinmektedir (Gachomo 2004; Youssef et al 2008). Yerfıstığı ürünlerindeki aflatoksin kontiminasyonu insan ve hayvan sağlığı açısından ciddi sorunlar meydana getirmekte, hatta kimi zaman ölümle sonuçlanabilen hastalıklara yol açmaktadır (Bankole \& Adebanjo 2003; Craufurd et al 2006; Youssef et al 2008).

Tarımsal ürünlerde mikotoksin oluştuktan sonra toksin üretiminin kontrol altına alınmas1 mümkün olmamaktadır. Bu nedenle hasat, kurutma ve depolama dahil tüm ürün üretim aşamalarında mikotoksin oluşumunu baskılamak için mikotoksin yönetim stratejilerine dikkat edilmesi gerekmektedir (Cast 2003). Gidaların mikotoksinlerle kirlenmesinde çevre ve iklim koşulları kritik rol oynar. Fungus gelişimi ve mikotoksin oluşumu büyük oranda bulundukları ortamda mevcut substratın nem içeriğine, sıcaklığına ve çevre nisbi nem düzeyine bağlıdır (Lawlor et al 2002; Bankloe \& Adebanjo 2003; Liang et al 2006; Özlüoymak 2014).

Hasat zaman1, hasat, soldurma, kurutma ve depolama dönemlerinde meyve bozulmaları, hastalık etmeni fungusların büyümesi ve uygun koşullar yaratılması nedeniyle oluşan aflatoksin, özellikle çerezlik tüketimde ve hayvan yeminde 
önemli sorunlara neden olabilmektedir. Osmaniye bölgesi çiftçileri, hasat zamanı, hasat, soldurma, kurutma ve depolama gibi kültürel çalışmaların aflatoksin oluşumu üzerine önemli bir etkiye sahip olabileceğini göz ardı etmektedir. Bu çalışmada; Osmaniye'de, 2010-2011 üretim döneminde yerfıstığ1 yetiştiriciliğinde aflatoksin oluşumu üzerine hasat, kurutma ve depo öncesi pratiklerinin etkileri incelenmiştir. Bu amaçla, Osmaniye'de kurulan deneme alanında, aflatoksin oluşumunu baskılayabilecek hasat pratikleri uygulanmıştır. Diğer yandan, çiftçilerce rutin olarak yetiştiricilik yapılan yerfıstığı tarlalarında, aflatoksin ve hasat durumları takip edilmiştir. Aflatoksin oluşumunu en aza indirmek için bu gibi üretim faaliyetlerinin araştırılması ve araştırma sonuçlarının çiftçilere önerilmesi, bu çalışmanın amacını oluşturmuştur.

\section{Materyal ve Yöntem}

Çalışma, 2010-2011 yılları arasında deneme ve araştırma alanlarında yürütülmüştür. Deneme, ana ürün olarak Alahanlı köyünde; tesadüf blokları deneme desenine göre 3 tekrarlamalı kurulmuştur. Deneme, her blokta azot $(\mathrm{N})$, fosfor $(\mathrm{P})$, potasyum (K), azot+fosfor (NP), azot+potasyum (NK), fosfor+potasyum (PK), azot+fosfor+potasyum (NPK) olmak üzere 7 uygulama ve 1 kontrol parseli olacak şekilde kurulmuştur. Toprak analizi sonuçlarına göre yapılan uygulamalarda, taban gübresi olarak $20 \mathrm{~kg} \mathrm{da}^{-1}$ amonyum sülfat (\% 21 $\mathrm{N}), 10 \mathrm{~kg} \mathrm{da}^{-1}$ triple süper fosfat $\left(\% 43 \mathrm{P}_{2} \mathrm{O}_{5}\right)$ ve $10 \mathrm{~kg} \mathrm{da}^{-1}$ potasyum sülfat $\left(\% 50 \mathrm{~K}_{2} \mathrm{O}\right)$ gübreleri uygulanmıştır. Üst gübre uygulaması için bitki çiçeklenme evresinde, azot uygulaması yapılan parsellere (N, NP, NK, NPK) $30 \mathrm{~kg} \mathrm{da}^{-1}(9.9 \mathrm{~kg} \mathrm{~N}$ $\left.\mathrm{da}^{-1}\right)$ amonyum nitrat ( $\% 33 \mathrm{~N}$ ) gübresi azot kaynağ 1 olarak kullanılmıştır. Denemede, ekimde parsel büyüklügü̈; $4.2 \mathrm{~m}$ x $5.0 \mathrm{~m}$ olup, toplam parsel alanı $21 \mathrm{~m}^{2}$ ve her parsel 6 siradan oluşmuştur. Parsel arası $1.5 \mathrm{~m}$, bloklar arası $2.5 \mathrm{~m}$ boşluk bırakılmıştır. 2010-2011 yılında sira arası $70 \mathrm{~cm}$, sıra üzeri $12 \mathrm{~cm}$ olacak şekilde ekim mibzerle yapılmıştır. Denemede ekim derinliği $6 \mathrm{~cm}$ 'dir. Tohum çeşidi olarak NC 7 kullanılmıştır. Altı kez karık sulama yapılmıştır. 2010 yılında yerfistığı ekim 24.04.2010; hasat
07.09.2010; hasat sonrası bitkileri ters çevirerek soldurma 10.09.2010; kurutma 14.09.2010; depo öncesi eleme 18.09.2010 tarihinde ayrıca, 2011 yılında ise ekim 30.04.2011; hasat 16.09.2011; hasat sonras1 soldurma 18.09.2011; kurutma 22.09.2011; depo öncesi eleme 26.09.2011 tarihinde yapılmıştır. Araştırmada elde edilen verilere varyans analizi uygulanmıştır. Daha sonra LSD (0.05) çoklu karşılaştırma testi uygulanarak gruplandırılmıştır.

Deneme alanına ait toprak (0-30 cm derinlik) analiz sonuçlarına göre fosfor ( $\left.7.1 \mathrm{ve} 7.4 \mathrm{mg} \mathrm{kg}^{-1}\right)$ ve potasyum (42.0 ve $44.0 \mathrm{~kg} \mathrm{~K}_{2} \mathrm{O} \mathrm{da}^{-1}$ ) içeriğinin yeterli düzeyin altında, Ca $\left(4823.0-4642.0 \mathrm{mg} \mathrm{kg} \mathrm{kg}^{-1}\right), \mathrm{Mg}$ (1683.0-1514.0 mg kg-1), S (11.6-10.2 $\left.\mathrm{kg} \mathrm{da}^{-1}\right), \mathrm{Zn}$ (3.8-3.5 mg kg-1), Fe (5.7-5.7 mg kg-1), Cu (1.4-1.1 $\left.\mathrm{mg} \mathrm{kg}{ }^{-1}\right)$ ve $\mathrm{Mn}\left(6.6-4.5 \mathrm{mg} \mathrm{kg}^{-1}\right)$ değerlerinin yeterlilik düzeyinin üzerinde olduğu belirlenmiştir. Toprağın $\mathrm{pH}$ değeri ise 7.6 olup hafif alkali karakter taşıdığı, tuzsuz (\% 0.02-0.03) ve az düzeyde kireçli (1.9-4.2) olduğu görülmüştür. Ayrıca organik madde içeriği bakımından zayıf (\% 1.4-1.5) ve bünyesi kildir.

Ana ürün koşullarında 2010 yılında araştırma alanların ikisi Alahanlı $(1,2)$; biri Nohuttepe (3); üçü Çona $(4,5,6)$ alanı içindedir. 2011 yılında araştırma alanların ikisi Alahanlı $(1,2)$; ikisi Nohuttepe $(3,4)$ diğer ikisi de Çona $(5,6)$ köylerindedir. 2010 yılında 1, 2, 3, 4, 5 nolu araştırma alanlarında NC 7, 6 nolu araştırma alanında ise Halis Bey çeşidi; 2011 yılında 1, 2, 4, 5 ve 6 nolu araştırma alanlarında NC 7, 3 nolu araştırma alanında ise yine Halis Bey çeşidi yetiştirilmiştir.

\subsection{Yerfistığ hasat ve kurutma işlemi}

Yerfıstığı hasadında, bitkiler topraktan çıkarılıp ters çevrilerek meyveler yukarı gelecek şekilde tarlada birkaç gün soldurulduktan sonra kurutma işlemine geçilmiştir. Deneme alanlarında hasat elle yapılmış olup zedelenme, çatlama ve kırılma şeklinde kabuklara zarar verilmeden; kurutma işlemi güneşte gerçekleştirilmiştir. Kurutma ürünün toprakla temasını önleyecek ve havalanmayı sağlayacak bir bez üzerinde yapılmıştır. Araştırma alanlarında ise hasat pullukla, kurutma işlemi ise güneşte, eskiden beri geleneksel olarak çiftçilerce uygulanan toprak zemin üzerinde yapılmıştır. Tüm araştırma 
alanlarındaki hasat edilen meyveler, çiftçilerin belirlediği toprak alanlara (sergenler) serilmiştir. Karıştırıcı tırmıklarla meyveler, günün değişik zamanlarında alt üst edilmiştir.

\subsection{Yerfistığl tanelerinin olgunluk oranlarının belirlemesi}

Hasat öncesi meyve kabuğu soyma yöntemine göre olgunluk durumları belirlenmiştir. $\mathrm{Bu}$ yöntemde; deneme parseli ve araştırma alanını temsil edebilen yerlerden 3-5 bitki seçilip sökülmüş ve bunların meyveleri toplanarak sayılmıştır. Daha sonra bunların meyve kabuğu bir bıçak yardımıyla soyulmaya başlanmıştır. Kabuk rengi; kırmızıkahverengi olan meyveler bir kenara ayrilarak sayılmıştır. Elde edilen sayısal değer, toplam meyve sayısı değerine oranlanması ile bulunmuştur.

\subsection{Yerfistığı tanelerin nem içeriklerinin belirlenmesi}

Yerfistığı tanelerinin nem içerikleri için hasat, hasat sonras1, kurutma ve depo öncesi olmak üzere toplam dört dönemde örnekler alınmıştır. Yerfıstığı tanelerinin nem içeriklerinin belirlenmesinde etüv cihazı kullanılmıştır. Kabukları kırılmış yerfıstığı örneklerinin her birinden 100'er g tartılarak alınmış ve cam beher içerisine konulmuştur. Tane örneklerini, Pixton (1982)'nin bildirdiği yönteme göre $130{ }^{\circ} \mathrm{C}$ 'de 2-3 saat süre ile etüvde bekletilmiştir. Etüvden çıkarılan örneklerin soğumaları beklenmiş ve tekrar hassas tartımları yapılarak, kuru ağırlıkları belirlenmiştir. Böylece her bir örnek için kaybolan ağırlık, \% nem içeriği olarak saptanmıştır.

\subsection{Aflatoksin analizi için yerfistığı örneklerinin alınmast}

Deneme ve araştırma alanlarından hasat, hasat sonras1, kuruma ve depo öncesi dönemlerden alınan her bir örnek için, ürün yığının farklı yön ve derinliklerinden yaklaşık $5 \mathrm{~kg}$ tane örneği oluşturmak üzere, yığın büyüklüğüne göre 5-15 noktadan birincil örnekler alınıp karıştırılmıştır. $\mathrm{Bu}$ karışımdan $1 \mathrm{~kg}$ iç elde edilecek miktarda alt örnek temiz poşetlere konularak etiketlenip ve uygun koşullarda laboratuvara getirilmiştir.

\subsection{Yerfistı̆̆ örneklerine CD-ELISA uygulaması}

CD-ELISA testlerinde, Neogen Corporation Veratox toplam aflatoxin kitleri ve farklı seviyelerde $\left(\mu \mathrm{g} \mathrm{kg}^{-1}\right)$ toksin standartları kullanılmıştır. Örneklerin hazırlanması ve ekstraksiyonu Neogen Veratox'un önerdiği yöntemler kullanılarak yapılmıştır. Örneklerin ekstraksiyonunda \% 70’lik metanol kullanılmıştır. Her bir örnekten tesadüfî olarak alınan $50 \mathrm{~g}$ tane örneği öğütülmüştür. Öğütülmüş örneklerden $25 \mathrm{~g}$ alınmış ve $125 \mathrm{~mL} \%$ 70’lik metanol içerisinde $2 \mathrm{dk}$ yüksek devirde blendırdan geçirilmiştir. Tüm çalışmalar normal şartlarda oda sıcaklığı koşullarında yapılmıştır. Teste başlamadan 1 saat önce konjugat hazırlanmış ve test aşamasına kadar oda sıcaklığında bekletilmiştir. Test karışım çukurları içerisine $100 \mu \mathrm{L}$ konjugat eklenmiştir. Yerfistığ örneği süzüklerinden ve $0,5,15,50 \mu \mathrm{g}$ $\mathrm{kg}^{-1}$ hazır olarak temin edilen toksin standartlarından 100'er $\mu \mathrm{L}$ alınmış ve konjugat eklenmiştir. Karışımın homojen olması amaciyla 8 kanallı pipetör kullanılarak 3 kez çekilip bırakılmıştır. Karışımlardan $100 \mu \mathrm{L}$ alınıp daha önce antibody ile kaplanmış çukurlara eklenmiş ve $2 \mathrm{dk}$ oda sıcaklığında inkübe edilmiştir. İnkübasyondan sonra çukurlar boşaltılıp ve 5 defa distile su ile yıkanmıştır. Çok kanallı pipetör kullanılarak, her çukura $100 \mu \mathrm{L}$ substrat eklenmiş ve $3 \mathrm{dk}$ inkübe edilmiştir. Renk oluşumu meydana geldikten sonra $100 \mu \mathrm{L}$ stok solüsyonu eklenmiş ve $20 \mathrm{dk}$ içerisinde $650 \mathrm{~nm}$ 'de ELISA okuyucusunda 4 kez okuma yapılmıştır. Elisa sonuçları, elisa okuyucusu STATFAX cihazında $650 \mathrm{~nm}$ 'de okunarak elde edilmiştir.

\subsection{Yerfistığl tane örneklerine IAC-HPLC uygulanmast}

CD ELISA yöntemi ile yüksek aflatoksin içeriği belirlenen 18 yerfıstığı örneğine Gıda, Tarım ve Hayvancılık Bakanlığı, Mersin İl Kontrol Laboratuvarında IAC-HPLC uygulanmıştır. Örneklerin ekstraksiyonları ve Immuno Afinity Colon (IAC) uygulaması için Aflprep R-Biopharm Rhone Ltd'nin bildirdiği yöntemler ve total aflatoksin standard 1 olarak, Aflastandart IFU kullanılmıştır. Aflatoksin $\left(B_{1}, B_{2}, G_{1}, G_{2}\right)$ (HPCL) analizinde AOAC (2005) metodu kullanılmıştır. İyi 
homojenize edilmiş yerfistığ blender kabına tartılmış, üzerine $5 \mathrm{~g} \mathrm{NaCl}, 150 \mathrm{~mL}$ methanol, $100 \mathrm{~mL}$ su ilave edilmiştir. Yüksek hızda 2 dk karıştırılmıştır. Watman no: 4 süzgeç kağıdından süzülmüş, süzüntüden $10 \mathrm{~mL}$ alındıktan sonra üzerine $30 \mathrm{~mL}$ PBS ilave edilmiştir. Karışımından $20 \mathrm{~mL}$ Immunoaffinity kolondan geçirilir. Numune kolondan yaklaşık 3-4 $\mathrm{mL} \mathrm{dk}^{-1}$ hıla geçtikten sonra yine $3-5 \mathrm{~mL} \mathrm{dk}^{-1}$ hızla $20 \mathrm{~mL}$ su geçirilmiştir. Hava geçirilerek kolon kurutulmuş, filtratın geçirildiği kolon uygun bir vial içine oturtulduktan sonra kolona $1 \mathrm{~mL}$ methanol aktarılıp yerçekimi etkisiyle viale akması beklenmiştir. Kolondan aynı şekilde $1 \mathrm{~mL}$ de su geçirilmiş ve numune Aglient 1100 marka HPLC'ye enjeksiyon yapilacak hale getirilmiştir. Flüoresans detektör (em: $360 \mathrm{~nm}$ ex: $435 \mathrm{~nm}$ ), HPLC Kolonu, Mobil faz (Su-AsetonitrilMetanol 560+180+260, v/v/v şeklinde hazırlanmış, degaze edilmiş ve Kobra Cell türevlendirmesi için mobil fazın 1 litresine $120 \mathrm{mg} \mathrm{KBr}$ ve $4 \mathrm{~mol}$ $\mathrm{L}^{-1}$ 'lik $350 \mu \mathrm{L}$ nitrik asit ilave edilmiş) kullanılarak çalıştırılmıştır. Akış hızı $1 \mathrm{~mL} \mathrm{dk} \mathrm{dk}^{-1}$ HPLC Kolonu sabit sıcaklıkta $\left(\mathrm{T}=40^{\circ} \mathrm{C}\right)$ tutulmuştur. Sonuçlar $\mu \mathrm{g} \mathrm{kg}^{-1}$ (ppb) olarak ifade edilmiştir.

\section{Bulgular ve Tartışma}

\subsection{Deneme ve araştırma alanlarındaki yerfistı $\breve{l}$ tanelerinin olgunluk oranlart}

Deneme alanındaki yerfıstığı örneklerinin olgunluk oranları ortalama değerleri varyans analizi sonucunda birbirleri ile farklılık göstermemiştir. 2010-2011 y1lında ekime takiben sırası ile 135. ve 138. günde olgunluk durumları belirlenmiştir. 2010 yılına ait yerfıstığ 1 tanelerinin olgunluk oranları $\%$ 69.71-70.85, 2011 yılında ise bu oran \% 70.3471.75 arasında belirlenmiştir (Çizelge 1). 2010 yılı ekimi takiben, 1, 2, 3, 4, 6 nolu araştırma alanlarında sirasi ile 135., 144., 148., 151., 149. ve 138. günlerde; $\%$ 62.26-72.72 oranlarında olgunluk durumları belirlenmiştir 2011 y1lında ise ekime takiben 1, 2, 3, 4, 6 nolu araştırma alanlarında sırası ile 138., 145., 136., 152., 150. ve 155. günlerde olgun meyve oran1 \% 61.38-72.23 arasında belirlenmiştir (Çizelge 2).

NC 7 ve Halis Bey çeşitleri virginia grubuna dahil olmakla, yarı yatık bir gelişme göstermektedir
(Güvercin 2009). Yerfistıkları genel olarak 120150 günde hasat olgunluğuna gelmektedir. Ancak, virginia orta erkenci olgunlaşma grubunda yer alan çeşitler 130-140 gün içerisinde hasat edilmelidir. 150. günde (virginia tipi için 140 gün), geciken hasatta ginoforların çürümesi sonucu kapsül ve kapsülde kalite kaybı olmaktadır (Chapin 2011).

Çizelge 1- Deneme alanı 2010-2011 yılları yerfıstığı tanelerinin olgunluk oranları (\%)

Table 1- The maturity ratio of peanut seeds (\%) in the experimental area in the years of 2010 and 2011

\begin{tabular}{|c|c|c|}
\hline \multirow[b]{2}{*}{ Uygulamalar } & 2010 & 2011 \\
\hline & \multicolumn{2}{|c|}{$\begin{array}{c}\text { Yerfistiğg tanelerinin olgunluk } \\
\text { oranlarl (\%) }\end{array}$} \\
\hline $\mathrm{N}$ & 70.78 & 71.75 \\
\hline $\mathrm{P}$ & 70.70 & 71.05 \\
\hline K & 70.61 & 71.31 \\
\hline $\mathrm{N}+\mathrm{P}$ & 70.40 & 71.69 \\
\hline $\mathrm{N}+\mathrm{K}$ & 70.85 & 71.02 \\
\hline $\mathrm{P}+\mathrm{K}$ & 70.68 & 70.70 \\
\hline $\mathrm{N}+\mathrm{P}+\mathrm{K}$ & 71.20 & 71.72 \\
\hline Kontrol & 69.71 & 70.34 \\
\hline Ortalama & 70.62 & 71.20 \\
\hline $\operatorname{LSD}(\% 5)$ & öd & öd \\
\hline 2010-2011 Ortalama & \multicolumn{2}{|c|}{70.91} \\
\hline
\end{tabular}

öd, önemli değil; LSD, Least significant difference; N, azot; $\mathrm{P}$, fosfor; $\mathrm{K}$, potasyum

Çizelge 2- Araştırma alanları 2010-2011 yılları yerfistığı tanelerinin olgunluk oranları (\%)

Table 2- The maturity ratio of peanut seeds (\%) in the researh areas in the years of 2010 and 2011

\begin{tabular}{lcc}
\hline \multirow{2}{*}{ Araştırma alanları } & 2010 & 2011 \\
\cline { 2 - 3 } & $\begin{array}{c}\text { Yerfistı̆̆ tanelerinin } \\
\text { olgunluk oranları (\%) }\end{array}$ \\
\hline 1 & 70.41 & 72.23 \\
2 & 68.47 & 61.38 \\
3 & 64.18 & 71.84 \\
4 & 62.26 & 62.78 \\
5 & 64.57 & 63.29 \\
6 & 72.72 & 60.68 \\
\hline Ortalama & 67.69 & 65.37 \\
\hline 2010-2011 Ortalama & \multicolumn{2}{c}{66.53} \\
\hline
\end{tabular}


3.2. Deneme ve araştırma alanlarındaki hasat, hasat sonrası, kurutma ve depo öncesi dönemlerindeki yerfistı̆̆ tanelerinin nem içerikleri

Deneme alanından hasat, hasat sonrası, kurutma ve depo öncesi olmak üzere 4 dönemde alınan toplam 96 yerfıstığ 1 tane örneklerinin nem içerikleri belirlenmiştir. Yerfıstığı tanelerinin ortalama nem içerikleri değerlerine varyans analizi uygulanmış ve birbirleri arasında farklılık bulunmamıştır. 2010 dönemi hasat, hasat sonrası, kurutma ve depo öncesi dönemine ait nem içerikleri sırası ile $\%$ 24.58-25.14, \% 18.53-19.26, \% 10.33-11.38, $\%$ 9.84-10.11 arasında; 2011 döneminde ise sıras1 ile \% 24.36-25.40, \% 18.62-19.28, \% 10.75-11.47, \% 10.01-10.43 arasında belirlenmiştir (Çizelge 3). Araştırma alanlarından hasat, hasat sonrası, kurutma ve depo öncesi olmak üzere 4 dönemde alınan toplam 42 yerfıstığı tane örneklerinin nem içerikleri belirlenmiştir. 2010 yılına ait nem içerikleri sırası ile \% 21.44-24.62, \% 15.82-18.84, \% 14.18-15.43, $\%$ 12.34-14.23 arasında; 2011 yılında sirası ile $\%$ 20.23-24.95, \% 18.02-19.53, \% 15.17-16.93, \% 15.02-15.23 oranlarında tespit edilmiştir (Çizelge 4). 2010-2011 deneme ve araştırma alanlarında hasat, hasat sonrası, kurutma ve depo öncesi dönemlerine ait ortalama nem içerikleri Şekil 1'de verilmiştir.

Deneme ve araştırma alanlarından alınan yerfıstığı tanelerinin nem içerikleri, kurutma ve depolama öncesi dönemlerde farklılık göstermiştir. Hill et al (1983) tarafından yapılan bir çalışmada, 143. gün hasat edilen yerfistığı bitkilerinin ters çevrilerek meyvelerin yukarı gelecek şekilde iki gün soldurma işlemine tabi tutulması sonucu, nem içerikleri yaklaşık

Çizelge 3- Deneme alanında 2010-2011 yılları hasat, hasat sonrası, kurutma, depo öncesi dönemlerine ait yerfıstığı tanelerinin nem içerikleri $(\%)$

Table 3-Moisture content of peanut seeds (\%) in the experimental area at harvest, post-harvest, drying and prestorage periods in the years of 2010 and 2011

\begin{tabular}{|c|c|c|c|c|}
\hline \multirow[b]{2}{*}{ Uygulamalar } & \multicolumn{3}{|c|}{2010} & \multirow[b]{2}{*}{ Depo öncesi } \\
\hline & Hasat & Hasat sonrast & Kurutma & \\
\hline $\mathrm{N}$ & 24.87 & 18.84 & 10.33 & 9.84 \\
\hline $\mathrm{P}$ & 24.68 & 18.53 & 11.10 & 9.97 \\
\hline K & 24.92 & 18.93 & 10.73 & 10.09 \\
\hline $\mathrm{N}+\mathrm{P}$ & 24.82 & 18.98 & 11.38 & 10.00 \\
\hline $\mathrm{N}+\mathrm{K}$ & 25.14 & 18.77 & 11.32 & 10.05 \\
\hline $\mathrm{P}+\mathrm{K}$ & 24.58 & 19.12 & 11.16 & 10.11 \\
\hline $\mathrm{N}+\mathrm{P}+\mathrm{K}$ & 24.96 & 19.26 & 10.73 & 9.92 \\
\hline Kontrol & 24.82 & 19.05 & 11.03 & 10.09 \\
\hline Ortalama nem (\%) & 24.85 & 18.94 & 10.97 & 10.01 \\
\hline \multirow[t]{2}{*}{ LSD $(\% 5)$} & öd & öd & öd & öd \\
\hline & & 2011 & & \\
\hline $\mathrm{N}$ & 24.36 & 18.62 & 10.80 & 10.12 \\
\hline$P$ & 25.40 & 18.95 & 11.37 & 10.15 \\
\hline K & 24.84 & 18.75 & 11.08 & 10.19 \\
\hline $\mathrm{N}+\mathrm{P}$ & 25.07 & 18.81 & 11.32 & 10.05 \\
\hline $\mathrm{N}+\mathrm{K}$ & 24.49 & 18.82 & 10.75 & 10.01 \\
\hline $\mathrm{P}+\mathrm{K}$ & 25.21 & 18.96 & 11.06 & 10.27 \\
\hline $\mathrm{N}+\mathrm{P}+\mathrm{K}$ & 24.98 & 19.28 & 10.75 & 10.24 \\
\hline Kontrol & 24.94 & 18.86 & 11.47 & 10.43 \\
\hline Ort. & 24.91 & 18.88 & 11.07 & 10.18 \\
\hline LSD (\%5) & öd & öd & öd & öd \\
\hline 2010-2011 Ortalama nem (\%) & 24.88 & 18.91 & 11.02 & 10.09 \\
\hline
\end{tabular}

öd, önemli değil; LSD, Least significant difference; N, Azot; P, Fosfor; K, Potasyum 
Çizelge 4- Araştırma alanlarında 2010-2011 yılları hasat, hasat sonrası, kurutma, depo öncesi dönemlerine ait yerfıstı̆̆ tanelerinin nem içerikleri (\%)

Table 4- Moisture content of peanut seeds (\%) in the research areas at harvest, post-harvest, drying and prestorage periods in the years of 2010 and 2011

\begin{tabular}{lcccc}
\hline \multirow{2}{*}{ Araştırma alanlart } & \multicolumn{3}{c}{ 2010 } \\
\cline { 2 - 5 } 1 & Hasat & Hasat sonrast & Kurutma & Depo öncesi \\
\hline 2 & 24.62 & 18.84 & 14.22 & 12.34 \\
3 & 22.53 & 18.44 & 15.43 & 14.23 \\
4 & 22.12 & 16.72 & 14.97 & 13.64 \\
5 & 21.25 & 15.82 & 14.18 & - \\
6 & 21.44 & 16.85 & 14.81 & - \\
\hline Ortalama nem (\%) & 24.45 & 18.39 & 14.53 & - \\
\hline & 22.74 & 17.60 & 14.69 & 15.40 \\
\hline 1 & & & 2011 & - \\
2 & 24.95 & 19.52 & 15.86 & 15.23 \\
3 & 22.52 & 18.02 & 16.93 & 15.10 \\
4 & 24.86 & 19.15 & 16.77 & - \\
5 & 21.92 & 18.34 & 15.74 & - \\
6 & 21.61 & 19.53 & 16.23 & 15.12 \\
\hline Ortalama nem (\%) & 20.23 & 18.12 & 15.17 & 14.26 \\
\hline $2010-2011$ Ortalama nem (\%) & 22.68 & 18.61 & 16.12 & \\
\hline
\end{tabular}

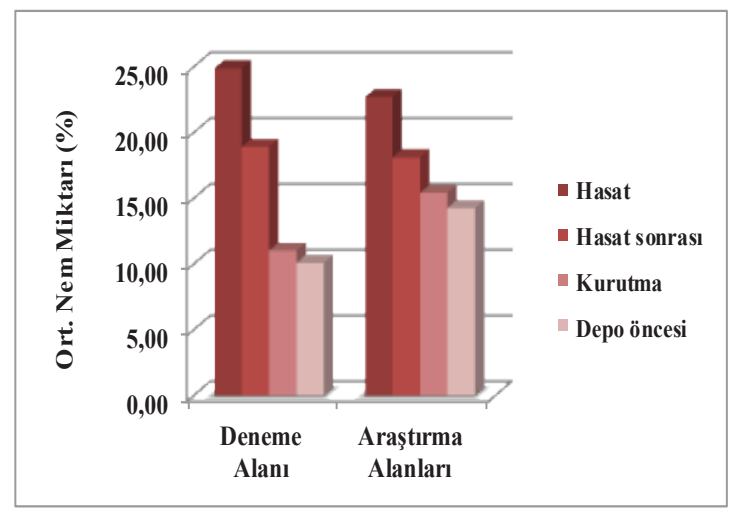

Şekil 1- Deneme ve araştırma alanlarında 20102011 yılları hasat, hasat sonrası, kurutma ve depo öncesi dönemlerine ait ortalama nem miktarları

Figure 1- The average moisture contents in the trial and research areas in the years of 2010 and 2011 at harvest, post-harvest, drying and pre-storage periods

\% 20-25 arasında değişmiştir. Bu bulgu, 2010 ve 2011 yıllarındaki 2 nolu araştırma alanlarında 144. ve 145. günlerde hasat edilen yerfistıklarının nem içerikleri sonucunu destekler niteliktedir.
Yerfıstığı tane nem içeriği hasat sonrasında \% 18-24 olması gerekir (Sanders 1995). Deneme ve araştırma alanlarından hasat döneminde alınan 28 yerfistığı örneğinde nem içeriği \% 20.23 ile $\% 25.40$ arasında değişiklik göstermiştir. Kabuklu yerfistığ 1 nem içeriğinin kurutma ve depolama aşamalarında yaklaşık \% 11 olması gerekir (Sanders 1995). Kurutma ve depolama öncesinde alınan 50 örnekte ise \% 9.84 ile \% 16.93 arasında değişen nem içerikleri belirlenmiştir. Araştırma örnekleri uygun şekilde kurutulmadıklarından, kurutma sonrası yerfistıklarının \% 11 'in üzerinde bir nem içeriğine sahip oldukları saptanmıştır. Depo öncesi yüksek nem içerikli, yerfıstıklarının uygun olmayan koşullarda depolandıklarında fungus gelişimi ve toksin üretimi için uygun ortam yaratılabilir (Bankole \& Adebanjo 2003; Shapira \& Paster 2004; Kaaya \& Warren 2005; Gürsoy \& Biçici 2006; Okello et al 2010a; Lavkor 2013).

Deneme alanlarında hasat elle yapılmış olup, hasattan sonra kurutma işlemi güneşte yapılmıştır. Kurutma ürünün toprakla temasını önleyecek ve havalanmayı sağlayacak bir bez üzerinde yapılmıştır. Yığın oluşturmadan bezler üzerinde 
yapılan kurutmada, yerfistıklarının nem içerikleri uygun seviyeye getirilip, kurutma sonras1 nem içeriği \% 10-11'e çekilmiştir (Sanders et al 1982; DeBruce 2010). Hasattan sonra depolama için kabuklu yerfistıklarında \% 10.00-11.00, kabuksuz yerfistıklarında \% 7.00-8.00 olmas1 gerekmektedir (Biçici 2008). Osmaniye bölgesinde hasat edilen yerfıstıkları sergen alanlarına taşınmakta ve toprak üzerinde yığınlar halinde bırakılmaktadır. Toprak yüzeyinde hiçbir önlem almaksızın bekletilen yerfistıkları hem yeterince havalandırılmadı̆̆ için kurumamakta ve yerfıstığı çevresindeki hava içerisinde bulunan patojenlere karşı hassas duruma gelmektedir. Böylece tarla ve hasat dönemlerinde yerfıstığ 1 meyveleri üzerinde bulaşmış başta Aspergillus cinsine dahil fungusların gelişmeleri için uygun ortam sağlanmaktadır (Biçici 1980; Kaaya \& Warren 2005; Gürsoy \& Biçici 2006; Okello et al 2010b; Lavkor 2013). Araştırma alanlarında çiftçilerce, benzer koşullarda yapılan kurutma işleminin, üründe yeterince kurutma sağlamadığı gözlenmiştir. Nitekim Endonezya'da benzer şekilde kurutma yapılan yerfıstıklarında, nem içerikleri
(\% 12.5-45.4) yüksek oranlarda saptanmış (Drahmaputra 1996). Gürsoy \& Biçici (2006), Çukurova bölgesinde yetiştirilen yerfıstıklarının kurutma ve depolama aşamalarında, bu oranın \% 10-18 arasında olduğunu ayrıca belirlemişlerdir.

\subsection{Deneme ve araştırma alanlarindan hasat edilen yerfistı̆̆ tanelerinin aflatoksin bulaşıklı̆̆ CD-ELISA test sonuçları}

Deneme alanında hasat, hasat sonrası, kurutma ve depo öncesi olmak üzere 4 ayrı dönemde, toplam 96 örnekten alınan yerfistığı tanelerinden CDELISA yöntemi ile aflatoksin kirliliği aranmıştır. $\mathrm{Bu}$ test sonuçlarına göre bulaşıklık belirlenmemiştir. Araştırma alanlarında 4 ayrı dönemde alınan 42 yerfıstığı tane örneğinin 41'inde aflatoksin bulaşıklığı saptanmıştır. Araştırma alanlarından alınan yerfıstığı tane örneklerinde belirlenen toplam aflatoksin içeriği sırası ile $0.1-8.2 \mu \mathrm{g} \mathrm{kg}^{-1}, 0.1-9.0$ $\mu \mathrm{g} \mathrm{kg}^{-1}$ seviyeleri arasında tespit edilmiştir Toksin ile bulaşı örneklerin tümü, ülkemizde uygulanan yasal tolerans değeri olan $10 \mu \mathrm{g} \mathrm{kg}^{-1}$ ' $1 \mathrm{n}$ altında bir değere sahip oldukları belirlenmiştir (Çizelge 5 ve Şekil 2).

Çizelge 5- Araştırma alanlarında 2010-2011 yılları hasat, hasat sonrası, kurutma, depo öncesi dönemlerine ait yerfıstığı tanelerinin aflatoksin içerikleri $\left(\mu \mathrm{g} \mathrm{kg}^{-1}\right)$

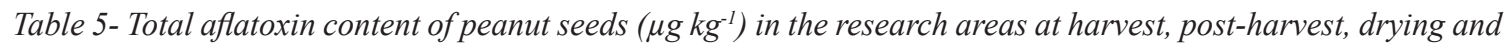
pre-storage periods in the years of 2010 and 2011

\begin{tabular}{lcccc}
\hline \multirow{2}{*}{ Araştırma alanlart } & \multicolumn{3}{c}{2010} \\
\cline { 2 - 5 } & Hasat & Hasat sonrast & Kurutma & Depo öncesi \\
\hline 1 & 0.1 & 2.4 & 6.2 & 4.0 \\
2 & 0.8 & 3.0 & 7.8 & 6.7 \\
3 & 0.8 & 2.9 & 8.2 & 5.2 \\
4 & 1.9 & 4.0 & 8.2 & - \\
5 & 1.8 & 3.2 & 6.6 & - \\
6 & 0.2 & 2.0 & 5.4 & 5.3 \\
\hline Ortalama aflatoksin $\left(\mu \mathrm{gg}^{-1}\right)$ & 0.9 & 2.9 & 7.1 & 7.4 \\
\hline & & & \\
\hline 1 & 0.1 & 2.3 & 7.8 & - \\
2 & 0.2 & 2.6 & 9.0 & 6.9 \\
3 & 0.0 & 1.7 & 7.2 & 8.6 \\
4 & 1.5 & 3.4 & 8.8 & - \\
5 & 1.6 & 4.0 & 8.9 & - \\
6 & 1.6 & 3.8 & 8.5 & 7.6 \\
\hline Ortalama aflatoksin $\left(\mu \mathrm{g} \mathrm{kg}{ }^{-1}\right)$ & 0.8 & 3.0 & & 6.47 \\
\hline
\end{tabular}

Tarım Bilimleri Dergisi - Journal of Agricultural Sciences 21 (2015) 394-405 

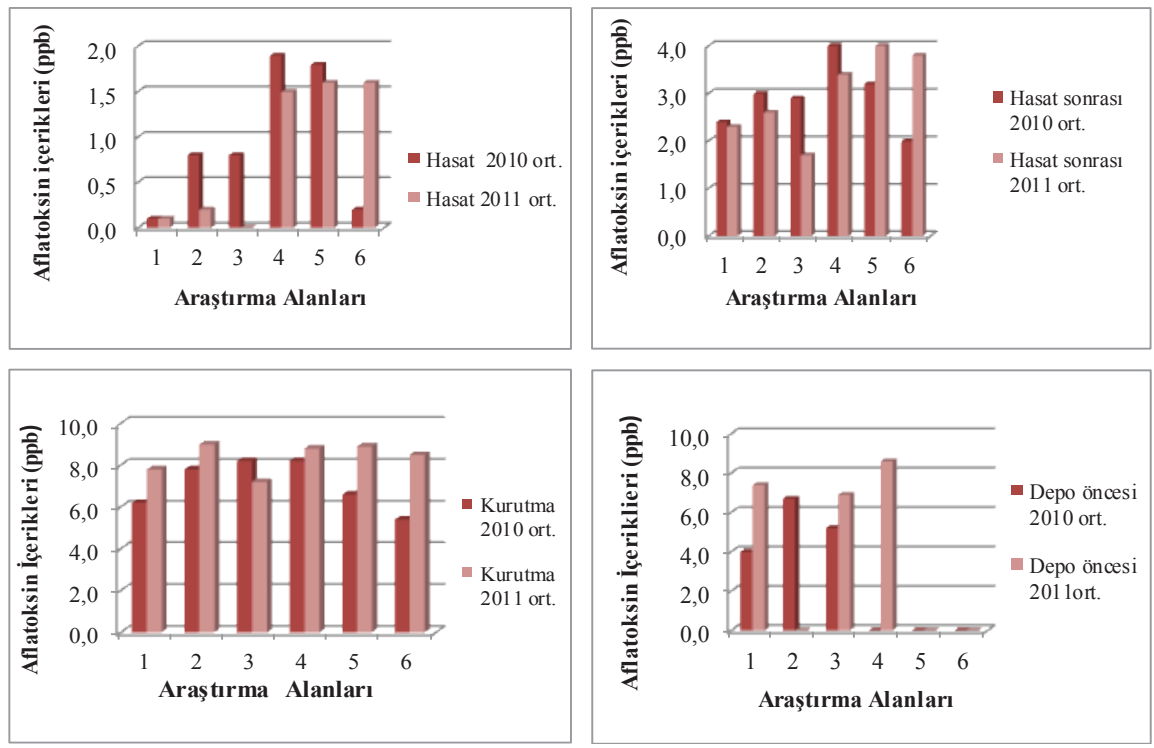

2010 yılı; 1, Alahanlı; 2, Alahanlı; 3, Nohuttepe; 4, 5, 6, Çona; 2011 yılı; 1, Alahanlı; 2, Alahanlı; 3, 4, Nohuttepe; 5, 6, Çona

Şekil 2- Araştırma alanlarında 2010-2011 yılları hasat, hasat sonrası, kurutma ve depo öncesi dönemlerine ait toplam aflatoksin sonuçları $\left(\mathrm{ppb}=\mu \mathrm{g} \mathbf{~ g}^{-1}\right)$

Figure 2-Total aflatoxin levels in the research areas in the years of 2010 and 2011 at harvest, post-harvest, drying and pre-storage periods $\left(p p b=\mu g \mathrm{~kg}^{-1}\right)$

Öncelikle birincil bulaşmanın, tarlada ve uygun olmayan kurutma sırasında olduğu düşünülmektedir. Yerfıstı̆̆ bitkisinin yetişme dönemi boyunca yapılan yanlışlıklar nedeni ile kalitede meydana gelen azalmalarla birlikte, meyvelerin mantar ve zararl istilasına uğraması, ayrıca nem ve sıcaklık gibi iklimsel şartlar ile bir araya geldiğinde aflatoksin oluşturan fungusların ikincil bulaşmaları ve gelişmelerinde artışa yol açabilmektedir (Pitt \& Hocking 2003; Cotty \& Garcia 2007; Atayde et al 2012).

Deneme alanlarında hasat elle yapılmış olup zedelenme, çatlama ve kırılma şeklinde kabuklara zarar verilmeden; kurutma işlemi güneşte yapılmıştır. Kurutma ürünün toprakla temasını önleyecek ve havalanmayı sağlayacak bir bez üzerinde yapılmıştır. Kurutmanın toprak üzerinde yapılmaması ve yerfıstıklarının çok ince bir şekilde yayılarak kurutulması, yerfistıklarında aflatoksin oluşturan fungus bulaşmaları ve aflatoksin oluşumu için bir engel olabilir. Ancak Kaaya \& Waren (2005) tarafından yapılan bir araştırmada, yerfıstı $\breve{ı}$ hasadını takiben ürünlerin toprak yüzeyinde polietilen plastik örtüler üzerinde kurumaya bırakılması şeklinde yerfıstıklarının tarlada güneş altında kurutulmasının oldukça yavaş olduğu ve potansiyel aflatoksin üretici fungusların gelişimine neden olduğu bildirilmiştir. Yalnız kaput bezinin polietilen plastik örtüye göre hava geçirme avantaj1, aflatoksin oluşumuna karşı kullanılabilirliğini artırmaktadır.

Araştırma alanlarında çiftçiler, hasat ettikleri yerfıstıklarını toprak üzerinde yığınlar halinde bırakarak kurutma yapmakta; yığınlar üzerinde gezerek karıştırma işlemini kürekle gerçekleştirmektedir. Zedelenen ve kırılan yerfistıkları, toprak yüzeyinde bekletildiği ve yeterince havalandırma olmadığı için yerfıstığı ürünü çevresindeki hava içerisinde bulunan patojenlere karşı hassas duruma gelmektedir. Böylece tarla ve hasat dönemlerinde yerfistığı meyveleri üzerine bulaşmış başta Aspergillus 
gibi fungusların gelişmeleri için uygun ortam sağlanmaktadır (Kaaya \& Warren 2005; Gürsoy \& Biçici 2006; Okello et al 2010a).

Diğer taraftan özellikle ham, tam olgunlaşmamış herhangi bir nedenle zarar görmüş veya tohum kabuğu zararlanmış, kotiledonları ayrılmış yerfıstığı taneleri aflatoksin üretimi için yüksek potansiyele sahiptir (Cole et al 1985; Tunail 2000; Biçici 2008; Okello et al 2010a). Araştırma alanlarında çiftçilerin üretilen yerfıstıklarını toprak üzerinde güneşte kurutma işlemi uzun zaman aldığı için, üründe potansiyel aflatoksin üretici fungusların gelişmesine neden olabilmeleri kuvvetle muhtemeldir.

Araştırma alanlarında depo öncesi örneklerin nem oranı ( $\%$ 13.40-15.12), kurutma dönemi örneklerine ait nem oranından (\% 14.69-16.12) çok az oranda düşük olduğu tespit edilmiştir. Depoya gitmeden elenen yerfistıkları, toprak ve diğer yabancı maddelerden kısmen de olsa arındığg için, aflatoksin kirliliği oluşumu daha az olasıdır (Kaaya \& Warren 2005; Okello et al 2010b). Kaçmaz (2006)'ın Osmaniye'de yaptığı çalışmada işlenmek amacıyla gelen yerfıstığı ürününün içerisinde \% 10 15 oranında kirlilik (taş, toprak, çöp, lif, fitık v.b.) barındırdığını belirtmiştir.

Farklı dönemlerde belirlenen aflatoksin bulaşıklığı karşılaştırıldığında; kurutma (5.4-9.0 $\mu \mathrm{g}$ $\left.\mathrm{kg}^{-1}\right)$ ve depo öncesi dönemde $\left(4.0-8.6 \mu \mathrm{g} \mathrm{kg}^{-1}\right)$, hasat (0.0-1.9 $\left.\mu \mathrm{g} \mathrm{kg}^{-1}\right)$ ve hasat sonrasina (1.7-4.0) göre daha yüksek bulunmuştur. Aflatoksin oluşumunun en fazla kurutma döneminde olduğu, sonra depo öncesi dönemde meydana geldiği belirlenmiştir. Örneklerin hasattan hemen sonra alındığı göz önüne alınırsa aflatoksin bulaşmalarının depo koşullarında devam edeceği ve dolayısı ile aflatoksin bulaşıklığının artacağı açıktır (Hell et al 2000; Cardwell et al 2001; Scheidegger \& Payne 2003; Bankole \& Adebanjo 2003; Cast 2003; Shapira \& Paster 2004; Kaaya \& Warren 2005; Gürsoy \& Biçici 2006; Okello et al 2010a; Lavkor 2013). Örneğin, Uganda'nın Kumi Bölgesinde yapılan bir çalışmada, aflatoksin bulaşmalarının yeni hasat edilmiş yerfıstıklarının \% 28'inde 0-5 $\mu \mathrm{g} \mathrm{kg}^{-1}$ iken, bu örnekler depolandıktan sonra \% 48'inde $0-22 \mu \mathrm{g} \mathrm{kg}^{-1}$ 'a arttı̆g 1 belirlenmiştir (Kaaya \& Warren 2005; Okello et al 2010a).

\subsection{Yerfistığı örneklerinde IAC-HPLC test sonuçları}

$\mathrm{Bu}$ çalışmada, aflatoksinle ilgili olarak CD-ELISA tekniği ile elde edilen sonuçların isabet düzeyini karşılaştırmak üzere, aynı örneklerde HPLC tekniği ile toksin aranmıştır. Bunun için, HPLC aletinin bulunduğu Mersin İl Kontrol Laboratuarında toksin analizi yaptırılmıştır.

2010 yılında CD-ELISA ile 6.6-8.2 $\mu \mathrm{g} \mathrm{kg}^{-1}$ düzeyi arasında değişen aflatoksin bulaşıklığı belirlenmiş toplam 5 yerfistığ örneği HPLC ile analiz edilmiştir. CD-ELISA ile 6.6, 6.7, 7.8, 8.2, 8.2 $\mu \mathrm{g} \mathrm{kg}{ }^{-1}$ toksin içeriğine sahip yerfıstığı tane örnekleri HPLC analizlerinde; 5.1, 6.1, 7.0, 7.4, $9.5 \mu \mathrm{g} \mathrm{kg}^{-1}$ gibi değerler göstermiştir. 2011 yılına ait 7.2-9.0 $\mu \mathrm{g}$ $\mathrm{kg}^{-1}$ düzeyi arasında değişen aflatoksin bulaşıklığı olan toplam 8 yerfistığı örneğine HPLC ile analizi yaptırılmıştır. CD-ELISA ile 7.2, 7.4, 7.8, 8.5, 8.6, $8.8,8.9,9.0 \mu \mathrm{g} \mathrm{kg}^{-1}$ toksin içeriğine sahip bu yerfistığ1 tane örnekleri HPLC analizi ile; 7.3, 7.3, 7.4, 7.8, 8.5, $9.5,9.5,10.3 \mu \mathrm{g} \mathrm{kg}-1$ düzeyinde aflatoksinle bulaşık bulunmuştur. Osmaniye bölgesinde, çeşitli yerfistığ 1 depolarından alınan yerfıstı ̆̆ örnekleri 11.4-19.9 $\mu \mathrm{g}$ $\mathrm{kg}^{-1}$ düzeyi arasında değişen aflatoksin bulaşıklığı olan toplam 5 adet yerfistığı örneği ayrıca HPLC ile analiz edilmiştir. CD-ELISA ile 11.4, 11.4, 11.8, 16.2, $19.9 \mu \mathrm{g} \mathrm{kg}^{-1}$ toksin içeriğine sahip bu yerfistı̆̆ 1 tane örnekleri HPLC analizi ile; 11.1, 13.1, 13.8, 18.9, $23.7 \mu \mathrm{g} \mathrm{kg}^{-1}$ düzeyinde bulaşık olarak saptanmıştır. Görüleceği üzere her iki yöntemle belirlenmiş aflatoksin kirlilikleri birbirine çok yakın olmuştur.

HPLC analiz sonuçlarında, CD-ELISA ile belirlenen değerlere yakın aflatoksin içerikleri tespit edilmiş, yerfıstığı örneklerinde HPLC analizleri sonucunda $B_{1}$ ve $B_{2}$ içeriği belirlenmiş, $\mathrm{G}_{1} \mathrm{ve}_{2}$ toksinlerinin bulunmadığ Aflatoksin $\mathrm{B}_{1}$ 'in doğal olarak oluşan ve canlılarda toksijenik özelliğe sahip en kanserojen aflatoksin formu olduğu bilinmektedir (Scheidegger \& Payne 2003; Alinezhad et al 2011). Yerfistığ1 aflatoksin oluşumu için duyarlı bir ürün olmasının yanı sıra, elde edilen $23.7 \mu \mathrm{g} \mathrm{kg}^{-1}$ toplam aflatoksin seviyesi hem FDA gibi uluslararası bir kuruluşun belirlediği tolerans seviyesi olan $20 \mu \mathrm{g} \mathrm{kg}^{-1}$ 'dan yüksek, hem de Türkiye'de uygulanan yasal tolerans sınırı olan 
$10 \mu \mathrm{g} \mathrm{kg}^{-1}$ 'ın yaklaşık iki katından fazladır. Bölgede yerfistığ 1 kurutma, depo öncesi ve depolama aşamasında şu anda önemli sorunlar olduğu ve önlemler alınmadığı sürece bu sorunun gelecekte artarak devam edeceği mutlaktır.

\section{Sonuçlar}

Bu çalışma sonuçları doğrultusunda farklı dönemlerde belirlenen aflatoksin bulaşıklığı karşılaştırıldığında; kurutma ve depo öncesi dönemde, hasat ve hasat sonrasına göre daha yüksek olarak belirlenmiştir. Böylece aflatoksin oluşumunun en fazla kurutma ve depo öncesi dönemde meydana geldiği belirlenmiştir. Örneklerin hasattan hemen sonra alındığı göz önüne alınırsa, aflatoksin bulaşmalarının depo koşullarında devam edeceği ve dolayısı ile aflatoksin bulaşıklığının artabileceği düşünülmektedir. Ayrıca depo öncesi yerfıstıklarının yüksek nem içerikleri, uygun olmayan koşullarda depolandıklarında fungus gelişimi ve toksin üretimi için uygun ortam yaratılabileceği sonucuna varılmıştır.

\section{Kaynaklar}

Alinezhad S, Tolouee M, Kamalzadeh A, Motalebi A A, Nazeri M, Yasemi M, Shams-Ghahfarokhi M, Tolouei R \& Razzaghi-Abyaneh M (2011). Mycobiota and aflatoxin $\mathrm{B}_{1}$ contamination of rainbow trout (Oncorhinchus Mykiss) feed with emphasis to Aspergillus section Flavi. Iranian Journal of Fisheries 10(3): $363-374$

Amaike S \& Keller N P (2011). Aspergillus flavus. Annual Review of Phytopathology 49: 107-133

AOAC (2005). Journal of AOAC International 88(2)

Arıoğlu H (2007). Yağ Bitkileri Yetiştirme ve Islahı. Çukurova Üniversitesi, Ziraat Fakültesi, Ders Kitapları Yayın No: A-70, Çukurova Üniversitesi Ziraat Fakültesi Ofset Atölyesi: 204, Adana

Atayde D D, Reis T A, Godoy I J, Zorzete P, Reis G M \& Corrêa B (2012). Mycobiota and aflatoxins in a peanut variety grown in different regions in The State of São Paulo, Brazil. In: J Correll, J V Cross, F P F Reay-Jones, J C Streibig \& S N Wegulo (Eds), Crop Protection, Elsevier, pp.7-12

Bankole S A \& Adebanjo A (2003). Mycotoxins in food in West Africa: Current situation and possibilities of controlling it. African Journal of Biotechnology 2(9): $254-263$
Biçici M (1980). Yerfistığı (Arachis hypoganea L.) ürününde tarla, hasat, kurutma ve depo dönemlerinde Aspergillus niger Van Tieghem ve Aspergillus flavus Link tarafindan oluşturulan hastalık ve aflatoksin üzerine araştırmalar. Doktora Tezi, Çukurova Üniversitesi Fen Bilimleri Enstitüsü, Adana

Biçiçi M (2008). Yerfistığında hastalık ve aflatoksin sorunları. http://tyhm.cu.edu.tr/Tr/detay.aspx?pageId=1487 (Erişîm tarihi: 10.09.2012)

Cardwell K F, Hounsa A, Egal S, Wild C, Turner P C, Gong Y \& Hall A (2001). The costs of aflatoxin contaminated foods in West Africa. http://www. apsnet.org/online/feature/mycotoxin/ (Erişim tarihi: 24.12.2008)

Cast (2003). Mycotoxins: Risks in plants, animals and human systems. Council for Agricultural Sciences and Technology, Ames, Iowa

Chapin J W (2011). Peanut money-maker production guide. Clemson Extension Peanut Specialist. Circular 588, South Carolina

Cole R J, Sanders T H, Hill R A \& Blankenship P D (1985). Mean geocarposphere temperatures that induce preharvest aflatoxin contamination of peanuts under drought stress. Mycopathologia 91(1): 41-46

Cotty P \& Garcia R J (2007). Influences of climate on aflatoxin producing fungi and aflatoxin contamination. International Journal of Food Microbiology 119(1-2): 109-115

Craufurd P Q, Prasard P V, Waliyar F \& Taheri A (2006). Drought, pod yield, pre-harvest Aspergillus infection and aflatoxin contamination on peanut in Niger. Field Crops Research 98(1): 20-29

DeBruce M T (2010). Influence of moisture content on quality and shelf- life of oil roasted Virginia-type peanuts. Food Degree of Master of Science, North Carolina State University, USA

Drahmaputra O S (1996). Fungi isolated from groundnuts in some locations of West Java. Biotropia 9: 15-25

Gachomo E W, Mutitu E W \& Kotchoni O S (2004). Diversity of fungal species associated with peanuts in storage and the levels of aflatoxins in infected samples. International Journal of Agriculture \& Biology 6(6): 955-959

GIBSA (2006). Grain fungal diseases and mycotoxin reference. Grain Inspection, Packers and Stockyards Administration Tecnical Services (GIBSA) Division, Cansas City 
Gürsoy N \& Biçici M (2006). Çukurova Bölgesinde yetiştirilen yerfıstıklarında hasat, kurutma ve depolama kademelerinde aflatoksin oluşumu. Gıda Teknoloji Dergisi 31(4): 209-215

Güvercin E (2009). Farklı yerfıstığı çeşitlerinde bakteri aşılaması ve demir uygulamasının nodülasyon ve verime etkisi. Doktora tezi, Çukurova Üniversitesi Fen Bilimleri Enstitüsü (Basılmamış), Adana

Hell K, Cardwell, K F, Setamou M \& Poehling H M (2000). The influence of storage practices on aflatoxin contamination in maize in four agroecological zones of Benin, West Africa. Journal of Stored Products Research 36(4): 365-382

Hill R A, Blankship P D, Cole R J \& Sanders T H (1983). Effects of soil moisture and temperature on preharvest invasion of peanuts by the Aspergillus flavus group and subsequent aflatoxin development. Applied and Environmental Microbiology 45(2): 355-736

Kaaya N A \& Warren H L (2005). A review of past and present research on aflatoxin in Uganda. African Journal of Food Agriculture and Nutritional Development (AJFAND) 5: 1-18

Kaçmaz A (2006). Yerfistığı işleme teknolojisi ve bu amaçla kullanılan makinelerin iş başarılarının değerlendirilmesi üzerine bir araştırma. Yüksek lisans tezi, Çukurova Üniversitesi, Fen Bilimleri Enstitüsü (Basılmamış), Adana

Lavkor I (2013). Yerfistığı tarımında uygun kültürel işlemler ve hastalık yönetim pratikleri ile hastalık ve aflatoksin oluşumunun önlenmesi. Doktora tezi, Çukurova Üniversitesi Fen Bilimleri Enstitüsü (Basılmamış), Adana

Lawlor P G, Lynch P B, Gardiner G E, Caffrey P J \& O'doherty J V (2002). Effect of liquid feeding weaned pigs on growth performance to harvest. Journal of Animal Science 80: 1725-1735

Liang X Q, Luo M \& Guo B Z (2006). Resistance mechanisim to Aspergillus flavus infection and aflatoxin contimination in peanut (Arachis hypogaea). Plant Pathology Journal 5(1): 115-124

Negedu A, Atawodi S E, Ameh J B, Umoh V J \& Tanko H Y (2011). Economic and health perspectives of mycotoxins: A review. Continental Journal of Biomedical Sciences 5(1): 5-26

Okello D K, Kaaya A N, Bisikwa J, Were M \& Oloka H (2010a). Management of Aflatoxins in Groundnuts: A manual for Farmers, Processors, Traders and Consumers in Uganda. National Agricultural Research Organisation, Uganda
Okello D K, Biruma M \& Deom C M (2010b). Overview of groundnuts research in Uganda: Past, present and future. African Journal of Biotechnology 9(39): 6448-6459

Özlüoymak Ö B (2014). Development of a UV-based imaging system for real-time detection and separation of dried figs contaminated with aflatoxins. Tartm Bilimleri Dergisi - Journal of Agricultural Sciences 20(3): 302-316

Pitt J I \& Hocking A D (2003). Current knowledge of fungi and mycotoxins associated with food commodities in Southeast Asia. In: E Highley \& G J Johnson (Eds), Mycotoxin Contamination in Grains, Canberra, Australia, pp. 5-11

Pixton S W (1982). The importance of moisture and equilibrium relative humidity in stored products. In: Robson A D (Ed), Zinc in Soils and Plants, Kluwer Academic Publishers, Dordrecht, pp. 90-106

Sanders T H, Schubert A M \& Pattee H E (1982). Maturity methodology and postharvest physiology. In: $\mathrm{H}$ E Pattee \& C T Young (Eds), Peanut Science and Technology Yoakum, Texas, pp. 624-654

Sanders T H (1995). Harvesting, storage and quality of peanuts. In: Melouk H A \& Shokes F M (Eds), Peanuts Health Management, Phytopath. Soc. Pres, St. Paul, MN, pp. 23-31

Scheidegger K A \& Payne G A (2003). Unlocking the secrets of Aspergillus flavus from pathogenicity to functional genomics, Journal of Toxicology-Toxin Review 22(2-3): 423-459

Shapira R \& Paster N (2004). Control of mycotoxins. In: N Magan \& M Olsen (Eds) Storage and Techniques for their Decontamination in: Mycotoxins in Food, Woodhead Publishing Limited, Cambridge CB1 $6 \mathrm{AH}$, England

Tunail N (2000). Funguslar ve mikotoksinler. Gida Mikrobiyolojisi ve Uygulamaları, Genişletilmiş 2. Baskl, Ankara Üniversitesi Ziraat Fakültesi G1da Mühendisliği Bölümü Yayını, Sim Matbaası, Ankara, S. 522

TÜİK (2013). Türkiye İstatistik Kurumu. http://tuikapp. tuik.gov.tr/bitkiselapp/bitkisel.zul (Erişim tarihi 19.03.2014)

Youssef M S, Maghraby-El O M O \& Ibrahım Y M (2008). Mycobiota and mycotoxins of Egyptian peanut (Arachis hypogeae L.) seeds. International Journal of Botany 4(4): 349-360 